\title{
Urinary glucose unreliable as test for urinary tract infection in infancy
}

\author{
S. DOSA, I. B. HOUSTON, L. B. ALLEN, and R. JENNISON \\ From the Departments of Child Health and Clinical Pathology, St. Mary's Hospital, Manchester
}

\begin{abstract}
Dosa, S., Houston, I. B., Allen, L. B., and Jennison, R. (1973). Archives of Disease in Childhood, 48, 733. Urinary glucose unreliable as test for urinary tract infection in infancy. We tested the reliability of a paper strip test for urinary glucose in the diagnosis of urinary tract infection in babies. Though the number of false positive results $(0 \cdot 7 \%)$ was acceptable, $36 \%$ false negative results was regarded as unsatisfactory for a screening test for urinary tract infection, and its use cannot be recommended in this age group. This finding, however, is applicable only to urines collected from infants and in no way reflects upon the merits of the test when used in older children or adults.
\end{abstract}

In recent years a number of studies revealed that the incidence of urinary tract infection in newborn babies lies between $0.3 \%$ and $2 \cdot 7 \%$ (James, 1959 ; Lincoln and Winberg, 1964; Smellie et al., 1964; O'Brien et al., 1968; Littlewood, Kite, and Kite, 1969; Abbott, 1972). The most commonly reported figure is $1.0 \%$ to $1.5 \%$ with a preponderance of male infants, and the ninefold range of incidence is at least partly explained by differences in collection technique and criteria of diagnosis. It has become clear that collection of urine from babies for quantitative bacterial culture is a matter of some difficulty. The most widely used technique employing adhesive plastic bags is reported to yield grossly contaminated specimens in a high proportion of cases (Houston, 1963; Lam et al., 1967; Newman, O'Neill, and Parker, 1967). 'Clean voided' urine specimens are better, but a catheter specimen or urine collected by suprapubic aspiration is best of all (Pryles, Lüders, and Alkan, 1961; Virtanen, Oksanen, and Peltonen, 1962). There is, therefore, a need for a reliable screening test for urinary tract infection in the infant and preferably one which could also differentiate heavy contamination by bacteria from genuine intravesical bacteriuria.

Scherstén, Fritz, and Köhler (1967) reported that the concentration of glucose normally present in urine was markedly reduced in the presence of a urinary infection. This observation was applied to the diagnosis of urinary tract infection (Scherstén $e t$ $a l ., 1968)$ and developed into a paper strip test,

Received 13 February 1973.
Uriglox, designed to detect the small concentration of glucose normally present in the urine. However, the test depends on the bacteria multiplying in the urine for several hours and hence consuming the available glucose. Thus, the urine specimen should be collected after a long period without micturition and preferably while fasting-most conveniently the first morning urine specimen. Unfortunately, the micturition of infants cannot be regulated in this fashion, and the resultant specimen is randomly related to feeds and frequently will have been in the bladder for only 1 or 2 hours. In consequence, there was doubt about the reliability of this test in infancy. However, a large number of bacteria entering the urine during or after micturition (i.e. heavy contamination) would have little time to consume the urinary glucose. There was a possibility that the test would distinguish the large numbers of urinary bacteria due to contamination from those due to genuine infection.

For these reasons it was decided to make a critical comparison of two methods for the diagnosis of urinary tract infection in infancy, one a paper strip test for urinary glucose (Uriglox) and the other a quantitative bacterial culture.

\section{Patients and methods}

Two groups of infants were studied.

Group A. 422 healthy newborn infants $(274$ male, 148 female) between 3 and 10 days old, who were in the nurseries and special care unit of the hospital, had an initial urine specimen $\left(U_{1}\right)$ collected using an adhesive plastic bag. The genitalia had been prepared by 
washing with soap and water, rinsing with sterile water, and dabbing dry. The bags were inspected regularly; as soon as urine was passed it was transferred to a sterile container and refrigerated while awaiting culture. Each specimen was examined for the number of white cells in the uncentrifuged urine (Houston, 1963), for the number of bacteria by the technique of Leigh and Williams (1964), and for glucose by the paper strip test, Uriglox, (Scherstén et al., 1968). In this test the protruding tip of the paper changes to a blue-green colour when the urinary glucose concentration exceeds 2 to $3 \mathrm{mg} / 100 \mathrm{ml}$; failure to change colour indicates a lower glucose concentration and a presumption of bacterial growth in the urine.

If the number of bacteria exceeded $100,000 / \mathrm{ml}$ urine or if the test for glucose were abnormal (i.e. no colour change), then next day a second urine specimen $\left(U_{2}\right)$ was obtained usually by 'clean catch' without the use of a plastic bag and after the same preliminary cleansing as for $U_{1}$. The same series of tests were performed and if either bacterial count or urinary glucose test proved to be abnormal then the tests were repeated on yet a third urine specimen $\left(\mathrm{U}_{3}\right)$ obtained by suprapubic aspiration of the bladder (SPA).

Group B. For comparison with group A, urine specimens were collected from 35 infants less than 12 months old suspected of having a urinary tract infection because earlier routine urine cultures had yielded $>10^{5}$ bacteria/ml urine. A single urine specimen was obtained from each baby by suprapubic aspiration and tests performed as for group A. 22 of these infants had a meningomyelocele, which may have led to some stasis of urine within the bladder.

In both groups the time elapsing between the previous feed and the urine collection was recorded. Any baby who started antibiotic therapy during the series of urine collections was excluded from the analysis.

\section{Results}

The results for group A are shown in Table I.
Of the 422 initial urine specimens, 66 were repeated, 63 because of large numbers of bacteria (all capable of fermenting glucose), 1 because of an abnormally low urinary glucose, and 2 because both tests were abnormal. Of these, 9 required further repetition by suprapubic aspiration and all were sterile, though in 1 the urinary glucose test was still abnormal. Thus none of the babies in group A proved to have a urinary tract infection, defined as the presence of $>10^{5} \mathrm{bacteria} / \mathrm{ml}$ in urine obtained by suprapubic aspiration. A single $U_{1}$ was sterile but with an abnormal glucose test, and that same baby was the only case with similar results recorded in $U_{2}$ and $U_{8}$. Regrettably this baby's blood glucose level was not measured, but it had no clinical evidence of hypoglycaemia - the urine examination was repeated when the baby was 2 weeks old and was normal in all respects. In 2 other babies the urinary glucose was abnormal in $U_{1}$, these specimens also contained $>10^{5}$ bacteria $/ \mathrm{ml}$ urine but $<10$ white cells $/ \mathrm{mm}$; both babies yielded normal urine in all respects when $\mathrm{U}_{2}$ was examined next day.

Table I also shows the results of the single urine examination on babies of group B. Of these 36 babies, 25 had sterile urine when the specimen was obtained by suprapubic aspiration and did not have an infection. 11 specimens yielded $>10^{5}$ bacteria/ml urine, and in 7 of these the urinary glucose test was abnormal. 5 of these examples of bacteriuria were in babies with meningomyeloceles of whom 3 showed abnormally low concentrations of urinary glucose. The four infected specimens with normal glucose concentrations all contained bacterial species capable of fermenting glucose (Proteus 1, Esch. coli 1, and Klebsiella 2).

Esch. coli was the organism in $64 \%$ of the genuinely infected specimens of group B and in $81 \%$

TABLE I

Comparison of bacterial counts and urinary glucose tests

\begin{tabular}{|c|c|c|c|c|c|c|c|}
\hline \multirow{4}{*}{$\begin{array}{c}\text { Urine } \\
\text { specimens }\end{array}$} & \multicolumn{6}{|c|}{ Bacterial count $/ \mathrm{ml}$} & \multirow{4}{*}{ Totals } \\
\hline & \multirow{2}{*}{\multicolumn{2}{|c|}{$\frac{>10^{5}}{\text { Urinary glucose test }}$}} & \multirow{2}{*}{\multicolumn{2}{|c|}{$\frac{<10^{5}}{\text { Urinary glucose test }}$}} & \multirow{2}{*}{\multicolumn{2}{|c|}{$\frac{\text { Sterile }}{\text { Urinary glucose test }}$}} & \\
\hline & & & & & & & \\
\hline & Abnormal & Normal & Abnormal & Normal & Abnormal & Normal & \\
\hline $\begin{array}{l}\text { Group A } \\
U_{1} \text { (initial) } \\
U_{2} \text { (1st repeat) } \\
U_{3} \text { (2nd repeat) }\end{array}$ & $\begin{array}{l}2^{\star} \\
0 \\
0\end{array}$ & $\begin{array}{l}63^{\star} \\
8^{\star} \\
0\end{array}$ & $\begin{array}{l}0 \\
0 \\
0\end{array}$ & $\begin{array}{r}98 \\
30 \\
0\end{array}$ & $\begin{array}{l}1^{\star} \\
1^{\star} \\
1\end{array}$ & $\begin{array}{r}258 \\
27 \\
8\end{array}$ & $\begin{array}{r}422 \\
66 \\
9\end{array}$ \\
\hline$\underset{U}{\text { Group B }}$ & 7 & 4 & 0 & 0 & 0 & 25 & 36 \\
\hline
\end{tabular}

$\star$ Tests repeated next day. 
of those $U_{1}$ specimens from group $A$ which contained more than $100,000 \mathrm{bacteria} / \mathrm{ml}$ urine but were none the less regarded as contaminated; Proteus sp. was next in frequency in both groups. Only $7 \%$ of these same contaminated $U_{1}$ specimens yielded a mixed growth of different bacterial species. Thus, the type of bacterium and its presence in pure culture have been of little value in this series for discriminating between contaminated and infected urine samples.

Table II shows the results of the leucocyte counts performed upon $U_{1}$ (group $A$ ) and urine specimens from group B. There is a close but not invariable correlation between leucocyturia and infection, but a small percentage of normal babies also produce urine containing large numbers of leucocytes.

Table III sets out false positive and false negative rates for a variety of defined criteria. For this analysis all specimens derived from babies in group A were regarded as not truly infected and abnormal results in this group are therefore 'false positives'. For comparison, 11 babies from group $B$ were found to have infections (as defined by bacteriuria, see above); a normal result in this group is therefore a 'false negative'. There can be no false negatives under the heading 'bacteriuria' since the infected specimens are defined by the presence of $>10^{5}$ bacteria/ml urine.

\section{Discussion}

The false positive rate of $0.7 \%$ is entirely acceptable in a screening procedure, for each abnormal result is merely an indication for more precise tests. Of greater interest, from a total of 73 specimens (Table I) classified as contaminated but containing $>10^{5}$ bacteria $/ \mathrm{ml}$, only 2 yielded an abnormal test for glucose. In this respect, therefore, urinary glucose testing gave a more accurate prediction of normality than bacterial culture. Unfortunately, 4 of 11 (36\%) infected specimens (from group B) had a normal test for urinary glucose, and such a high false negative rate makes it unacceptable as a screening test for urinary tract infection in infancy. This conclusion is reinforced by the finding of false negative results in babies with meningomyeloceles in most of whom urinary glucose consumption is likely to be enhanced by intravesical urinary stasis.

This disappointing result is probably attributable to the shorter time which many urine specimens remain in an infant's bladder compared with the overnight urine specimen recommended for older individuals (Scherstén et al., 1968; Zager, Kalmanson, and Guze, 1969; Papanayiotou et al., 1970). In addition, it is known that many of the present urine specimens were necessarily obtained

TABLE II

Leucocyte content of urine collected per urethram and by suprapubic aspiration (SPA)

\begin{tabular}{|c|c|c|c|c|c|}
\hline & \multirow{2}{*}{$\begin{array}{l}\text { Collection technique } \\
\text { and diagnosis }\end{array}$} & \multicolumn{3}{|c|}{ Leucocytes $/ \mathrm{mm}^{3}$} & \multirow{2}{*}{ Totals } \\
\hline & & $0-10$ & $11-100$ & $>100$ & \\
\hline $\begin{array}{l}\text { Group A } \\
\mathbf{U}_{1} \\
\mathbf{U}_{3} \\
\text { Group B } \\
\underset{\mathbf{U}}{\mathbf{U}}\end{array}$ & $\begin{array}{l}\text { Perurethral uninfected } \\
\text { SPA uninfected } \\
\text { SPA uninfected } \\
\text { SPA infected }\end{array}$ & $\left.\begin{array}{r}405 \\
9 \\
25\end{array}\right\} 34$ & $\begin{array}{l}4 \\
0\end{array}$ & $\begin{array}{r}13 \\
0\end{array}$ & \}$_{25}^{422} 934$ \\
\hline
\end{tabular}

TABLE III

False positive and false negative rates for bacteriuria, leucocyturia, and urinary glucose test

\begin{tabular}{|c|c|c|c|c|}
\hline & \multicolumn{2}{|c|}{ Group A: $\mathbf{U}_{1}$ uninfected } & \multicolumn{2}{|c|}{ Group B: U infected } \\
\hline & Criterion used & False positives & Criterion used & False negatives \\
\hline $\begin{array}{l}\text { Bacteriuria } \\
\text { Urine glucose test } \\
\text { Leucocyturia }\end{array}$ & $\begin{array}{c}>10^{5} / \mathrm{ml} \\
\text { Abnormal } \\
>10 / \mathrm{mm}^{3} \\
>100 / \mathrm{mm}^{3}\end{array}$ & $\begin{array}{c}65 / 422(15 \%) \\
3 / 422(0 \cdot 7 \%) \\
17 / 422(4 \%) \\
13 / 422(3 \%)\end{array}$ & $\begin{array}{c}<10^{5} / \mathrm{ml} \\
\text { Normal } \\
0-10 / \mathrm{mm}^{3} \\
0-100 / \mathrm{mm}^{3}\end{array}$ & $\begin{array}{c}- \\
4 / 11(36 \%) \\
1 / 11(9 \%) \\
3 / 11(27 \%)\end{array}$ \\
\hline
\end{tabular}


shortly after a feed, when urine glucose concentrations are higher. It is of interest, therefore, that the 7 infected specimens with an abnormally low glucose concentration were all collected more than $1 \frac{1}{2}$ hours after feeding, whereas the 4 specimens with false negative results were collected before this time had elapsed and at the height of the postprandial glucose tide; the numbers are small, but conform to the predicted pattern.

Matsaniotis et al. (1971) reported a study in which none of 25 urine specimens from infants with urinary tract infections contained abnormally low concentrations of glucose (chemically measured) when collected without any fixed relation to meals or the last act of micturition. This represents a $100 \%$ false negative rate for the test. But on incubation of the urine for 8 hours at $37^{\circ} \mathrm{C}$, all developed an abnormally low glucose concentration. None of a control group of urine specimens reacted in this way to incubation, all containing more than $2 \mathrm{mg} / 100 \mathrm{ml}$ glucose before and after incubation. However, the controls were selected because they had 'negative' urine cultures, and before postcollection incubation of the urine is adopted as a solution to the problem a control group of uninfected but heavily contaminated urine specimens should be tested in this way. It is with this group of babies that confusion mainly arises. Postcollection incubation was not practised in the present study, but the procedure merits further investigation.

Many of the foregoing conclusions have been based on the premise that all of the babies in group A were uninfected because one of a sequence of urine specimens contained few or no bacteria. It is possible that some of the 65 specimens $U_{1}$ (Table III), regarded as highly contaminated, were actually infected but cleared spontaneously during the sequence of collections covering 24 to 48 hours. These would resemble the babies reported by Abbott (1970) whose bacteriuria cleared spontaneously after intervals of 5 to 10 days. However, only 2 of the 65 urine specimens $\left(U_{1}\right)$ regarded as contaminated had an abnormal test for urinary glucose, and if these were the only infected specimens (making an assumption producing the maximum possible disadvantageous error in the figures), then their transfer to group B (infected urines) would still not reduce the rate of false negative results to an acceptable level. This possible underdiagnosis may explain our failure to find any infection in $\mathbf{4 2 2}$ babies despite the fact that many of the present patients were born early and perhaps were more likely to develop a urinary tract infection (Littlewood, 1972). Abbott

(1972) reported an incidence of $1.0 \%$ urinary infections in a series of newborn babies, but apparently any level of bacteriuria in the suprapubic urine specimens was regarded as abnormal, not merely counts of $>10^{5} / \mathrm{ml}$. It is possible that this extension of the concept of bacteriuria is valid but there is room for discussion about this, and certainly the different criteria for infection could account for the discrepancy in incidence between that series and the present one. Other surveys of neonatal urinary tract infection vary so widely in the techniques of urine collection and criteria of diagnosis that it is difficult to make comparisons. Our experience suggests that only specimens obtained by suprapubic aspiration of the bladder (or perhaps transurethral catheterization) should be regarded as suitable for quantitative bacterial examination in this age group. Specimens collected by clean catch (O'Brien et al., 1968) may be nearly as good, but we find they still do not match this precision of diagnosis.

Little comment is required concerning the value of leucocyturia in diagnosis. Our findings confirm previous reports that while there is an undoubted correlation between bacteriuria and leucocyturia, a minority of infected specimens of urine contains normal numbers of white cells (Lam et al., 1967). Newman et al. (1967) also found that suprapubic aspiration of the bladder markedly reduced the number of leucocytes present in the urine as compared with 'clean-bag specimens'. The present series supports this observation, for all 34 nonbacteriuric urine specimens obtained by SPA contained not more than 10 leucocytes $/ \mathrm{mm}^{3}$, giving further evidence of the superiority of this technique for obtaining urine specimens in infancy.

We acknowledge the help of many nurses with the urine collections, and thank W. B. Warner \& Co. for their assistance and for generous supplies of Uriglox. S.D. was supported in this work by the Wellcome Trust.

\section{REFERENCES}

Abbott, G. D. (1970). Transient asymptomatic bacteriuria in infancy. British Medical fournal, 1, 207.

Abbott, G. D. (1972). Neonatal bacteriuria: a prospective study in 1,460 infants. British Medical fournal, 1, 267.

Houston, I. B. (1963). Pus cell and bacterial counts in the diagnosis of urinary tract infections in childhood. Archives of Disease in Childhood, 38, 600.

James, U. (1959). Urinary infection in the newborn. Lancet, 2, 1001.

Lam, C. N., Bremner, A. D., Maxwell, J. D., Murphy, A. V., and Low, W. J. (1967). Pyuria and bacteriuria. Archives of Disease in Childhood, 42, 275.

Leigh, D. A., and Williams, J. D. (1964). Method for the detection of significant bacteriuria in large groups of patients. Fournal of Clinical Pathology, 17, 498.

Lincoln, K., and Winberg, J. (1964). Studies of urinary tract infections in infancy and childhood. II. Quantitative estimation of bacteriuria in unselected neonates with special reference to the occurrence of asymptomatic infections. Acta Paediatrica, 53, 307. 
Littlewood, J. M. (1972). 66 infants with urinary tract infection in first month of life. Archives of Disease in Childhood, 47, 218.

Littlewood, J. M., Kite, P., and Kite, B. A. (1969). Incidence of neonatal urinary tract infection. Archives of Disease in Childhood, 44, 617.

Matsaniotis, M., Danelatou-Athanassiadou, C., Katerelos, C., Hartokalis, P., and Apostolopoulou, E. (1971). Low urinary glucose concentration: a reliable index of urinary tract infection. Fournal of Pediatrics, 78, 851.

Newman, C. G. H., O'Neill, P., and Parker, A. (1967). Pyuria in infancy and the role of suprapubic aspiration of urine in diagnosis of infection of urinary tract. British Medical fournal, $2,277$.

O'Brien, N. G., Carroll, R., Donovan, D. E., and Dundon, S. P. (1968). Bacteriuria and leucocyte excretion in the newborn. fournal of the Irish Medical Association, 61, 267.

Papanayiotou, P., Dontas, A. S., Papanayiotou, K., and Marketos, S. G. (1970). Mass detection of bacteriuria by combination of two screening tests. Postgraduate Medical fournal, 46, 425.

Pryles, C. W., Lüders, D., and Alkan, M. K. (1961). A comparative study of bacterial cultures and colony counts in paired specimens of urine obtained by catheter versus voiding from normal infants and infants with urinary tract infection. Pediatrics, 27, 17.
Scherstén, B., Dahlqvist, A., Fritz, H., Köhler, L., and Westlund, L. (1968). Screening for bacteriuria with a test paper for glucose. fournal of the American Medical Association, 204, 205.

Scherstén, B., Fritz, H., and Köhler, L. (1967). Subnormal concentration of urinary glucose as a sign of urinary tract infection in children. Acta Paediatrica Scandinavica, 56, Suppl. 177, 54.

Smellie, J. M., Hodson, C. J., Edwards, D., and Normand, I. C. S. (1964). Clinical and radiological features of urinary infection in childhood. British Medical fournal, 2, 1222.

Virtanen, S., Oksanen, T., and Peltonen, T. (1962). Colony counts and the diagnosis of urinary tract infection in infants and children. Annales Paediatriae Fenniae, 8, 269.

Zager, J., Kalmanson, G. M., and Guze, L. B. (1969). Dip stick determination of bacteriuria. American fournal of Medical Sciences, 258, 214.

Correspondence to Dr. I. B. Houston, Department of Child Health, St. Mary's Hospital, Manchester M13 oJH. 